\title{
Regulation of Synthesis of Glutamine Synthetase in Escherichia coli
}

\author{
By C. WU AND LUCY H. YUAN \\ Department of Internal Medicine, The University of Michigan, \\ Ann Arbor, Michigan 48I04, U.S.A.
}

(Accepted for publication 6 September 1967)

\begin{abstract}
SUMMAR Y
The synthesis of glutamine synthetase in Escherichia coli under different conditions was studied. The optimal concentration of ammonium sulphate in the growth medium for the enzyme synthesis was $0.4 \mathrm{~mm}$. When glucose was limiting growth the enzyme synthesis became dependent on oxygen. L-Glutamine repressed synthesis of the enzyme and, to a lesser extent, that of glutamate dehydrogenase. L-Arginine, L-asparagine, D-glutamine, Lmethionine and L-tryptophan also decreased synthesis of glutamine synthetase. On the other hand, L-glutamate induced the enzyme synthesis; L-isoleucine, L-leucine and L-valine also increased it. Acetyl-L-glutamine did not affect the enzyme synthesis. D-Glutamine was much less active than L-glutamine as a substrate in the $\gamma$-glutamyl transfer reaction. At low concentrations, both aza-L-serine and 6-diazo-5-oxo-L-norleucine increased the specific activity of glutamine synthetase in the bacteria.
\end{abstract}

\section{INTRODUCTION}

Glutamine occupies a central position in many metabolic pathways; thus, in microorganisms, the amide nitrogen of glutamine serves, among others, as the nitrogen source for carbamyl phosphate (Pierard \& Wiame, I964), nicotinamide-adenine dinucleotide (Preiss \& Handler, 1958), histidine (Neidle \& Waelsch, I959), p-aminobenzoic acid (Srinivasan \& Weiss, 196I) and glucosamine 6-phosphate (Ghosh, Blumenthal, Davidson \& Roseman, 1960). Therefore a control of the synthesis of glutamine might indirectly influence the synthesis and metabolism of a wide variety of compounds. The present study represents an effort to understand how the chemical environment of Escherichia coli strain w organisms affects the formation of glutamine synthetase, the enzyme which synthesizes glutamine from glutamic acid, ammonia and adenosine triphosphate.

\section{METHODS}

Growth of the bacteria. Escherichia coli strain w (American Type Culture Collection 9637) was grown in a nutrient broth medium (Difco Laboratories) until the logarithmic phase of growth had been reached. One $\mathrm{ml}$. of the broth culture served for inoculating I00 ml. of a defined basal medium which had the same composition as the one used by Davis \& Mingioli (1950), except that ammonium sulphate was decreased from I to $0.05 \mathrm{~g}$. $/ \mathrm{l}$. After the culture had been incubated at $37^{\circ}$ for $7 \mathrm{hr}$, the bacteria were harvested by centrifugation and washed once with saline. They were suspended in about 
$5 \mathrm{ml}$. of saline, so that the suspension gave a reading between 0.480 and 0.560 at $650 \mathrm{~m} \mu$ in a Coleman Junior spectrophotometer. Five drops of the bacterial suspension were pipetted into each of several $500 \mathrm{ml}$. conical flasks containing $200 \mathrm{ml}$. of the medium under study. Unless stated otherwise, the incubation was at $37^{\circ}$ for $\mathrm{I} 6 \mathrm{hr}$ with the flasks undisturbed. At the end of the incubation period, the amount of growth was determined by measuring the turbidity of the culture at $650 \mathrm{~m} \mu$ in the Coleman Junior spectrophotometer. In the following tables growth is always expressed in terms of absorbance readings with this instrument; a reading of 0.1 corresponded to $0.07 \mathrm{mg}$. dry bacteria $/ \mathrm{ml}$.

Preparation of cell-free extracts. The culture was chilled to $5^{\circ}$. From this point on, all operations were done at $5^{\circ}$. The'bacteria were harvested by centrifugation at $10,000 \mathrm{~g}$ for Io min. in a Servall SS-3 centrifuge. They were suspended in saline, centrifuged down, and finally suspended in $5 \mathrm{ml}$. of $0.0 \mathrm{I} \mathrm{M-tris} \mathrm{buffer,}(\mathrm{pH} \mathrm{8.2})$. The bacteria were disrupted by ultrasonic treatment (Io kc., Raytheon Mfg. Co., Waltham, Mass.) for Io min. The ultrasonically treated preparation was centrifuged at $17,000 \mathrm{~g}$ for $10 \mathrm{~min}$. The supernatant fluid served for all determinations reported in this study.

Enzyme assays. Glutamine synthetase activity was assayed as described previously

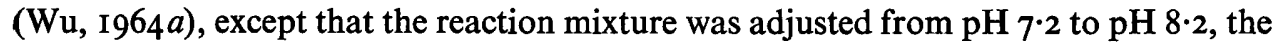
latter being the optimal $\mathrm{pH}$ value for the bacterial enzyme. One unit of the enzyme activity is defined as the amount of enzyme that will cause the formation of I $\mu$ mole $\gamma$-glutamylhydroxamate in $\mathrm{x} \mathrm{hr}$ at $37^{\circ}$. This assay procedure was used in all determinations for the synthetase activity reported in the following tables and figures. $\gamma$-Glutamyltransferase activity was assayed as before (Wu, $1964 b)$, but with the following modifications. The reaction mixture contained, per $4.5 \mathrm{ml} ., 250 \mu$ moles glutamine, $40 \mu$ moles $\mathrm{NH}_{2} \mathrm{OH}$ (adjusted to $\mathrm{pH} 7 \cdot 2$ ), Io $\mu$ moles $\mathrm{MnCl}_{2}, 5 \mu$ moles adenosine diphosphate and $45 \mu$ moles phosphate buffer $\left(\mathrm{pH}_{7 \cdot 2}\right.$ ). The expression for the transferase activity follows that for the synthetase activity. Glutamate dehydrogenase activity was determined according to the procedure of Kennan \& Cohen (I96I), except that dihydronicotinamide adenine dinucleotide phosphate $\left(\mathrm{NADPH}_{2}\right)$ replaced dihydronicotinamide adenine dinucleotide $\left(\mathrm{NADH}_{2}\right)$. The dehydrogenase activity is expressed as $\mu$ moles $\mathrm{NADPH}_{2}$ oxidized $/ \mathrm{mg}$. protein $/ \mathrm{min}$. at $25^{\circ}$. Protein was determined by the method of Lowry, Rosebrough, Farr \& Randall (I95I), with crystalline bovine albumin as a standard.

Chemicals. All chemicals were of the highest grade available commercially. Most amino acids were purchased from Nutritional Biochemicals Corporation (Cleveland, Ohio); acetyl-L-glutamine was obtained from Mann Research Laboratories (New York) and D-glutamine from Calbiochem (Los Angeles, California). Both aza-Lserine and 6-diazo-5-oxo-L-norleucine (DON) were gifts of Dr J. R. Dice (Parke, Davis and Company, Ann Arbor, Michigan). Because of their instability to heat, solutions of these compounds were sterilized by filtration through Millipore filters. Glucose solutions were autoclaved separately and added to the medium later.

\section{RESULTS}

The present study will describe first some observations on glutamine synthetase in the cell-free extract of Escherichia coli; the induction and repression of this enzyme in the bacteria by compounds of low molecular weight will be considered next. 
We found a gradual but continuing increase in glutamine synthetase activity in the cell-free extract when it was stored at $-20^{\circ}$ (Fig. I). The increase was largest on the first day, but it continued throughout the period of observation. At the end of 17 days of storage, the enzyme activity had doubled. In these experiments the extract was stored in vials, and one vial was thawed each time for the enzyme assay. We have not explored further the nature of this increase. However, Mecke, Wulff, Leiss \& Holzer (1966) identified in crude extracts of Escherichia coli a protein that inactivated glutamine synthetase in the presence of adenosine triphosphate $+\mathrm{Mg}^{2+}+$ glutamine; glutamate could replace glutamine (Mecke, Wulff \& Holzer, 1966). Hence, the increase in glutamine synthetase activity observed in the present work (Fig. I) might result from the spontaneous deterioration of this inactivating protein on storage. On the other hand, it is also possible that activation of glutamine synthetase by an unknown mechanism during storage might account for the increase in its activity. To ensure a uniform basis for comparing the activity data, the enzyme was assayed on the same day the cell-free extracts were prepared. In addition, each experiment was repeated more than once and the results averaged.

The bivalent cation requirement of the bacterial glutamine synthetase was like that of mammalian enzymes (Wu, 1964b; Schnackerz \& Jaenicke, 1966), in that $\mathrm{Mg}^{2+}$ proved to be the most effective activator in the synthesis reaction, and under the same conditions $\mathrm{Mn}^{2+}$ lacked activity. On the other hand, $\mathrm{Mn}^{2+}$ was required for the transfer reaction. Woolfolk, Shapiro \& Stadtman (1966) showed that, at lower $\mathrm{pH}$ values than those optimal with $\mathrm{Mg}^{2+}, \mathrm{Mn}^{2+}$ slightly activated the Escherichia coli enzyme in the synthesis reaction. The mechanism underlying the bivalent cation requirement for this enzyme remains to be elucidated.

Like the enzyme from rat liver ( $\mathrm{Wu}, \mathrm{I} 964 b)$, glutamine synthetase in the cell-free extract of Escherichia coli also showed a partial requirement for a sulfhydryl compound for optimal activity. The activity without added sulfhydryl compound averaged $70 \%$ of that with the addition. Cysteine (10 $\mathrm{mM}$ ) or dithiothreitol (2 mM) fulfilled this requirement; 2-mercaptoethanol was less effective.

Woolfolk et al. (1966) and Mecke \& Holzer (1966) observed that the synthesis of glutamine synthetase in Escherichia coli was affected by the ammonium sulphate concentration in the growth medium. We studied this phenomenon in greater detail. We found that higher concentrations of ammonium sulphate supported better growth, but the specific activity of the enzyme in these bacteria was greatly decreased, Fig. 2 shows the results. The highest specific activity was obtained in bacteria grown in the presence of $0.005 \%(\mathrm{w} / \mathrm{v})$ ammonium sulphate, although growth under these conditions was poor. There was a sharp decline in the specific activity when this concentration of ammonium sulphate was merely doubled. Therefore, in all subsequent experiments in this study, except where stated otherwise, the concentration of ammonium sulphate in the growth medium was $0.005 \%(\mathrm{w} / \mathrm{v} ; 0.38 \mathrm{mM})$.

Oxygen also affected the synthesis of glutamine synthetase in Escherichia coli, and this effect depended on the glucose concentration. The experiments were made with the flasks containing the inoculated medium either kept stationary, shaken on a rotary shaker, or aerated by bubbling air through a dispersion tube throughout the incubation period. Table I summarizes the results. The difference between shaking and aeration was slight and seems insignificant. With a given concentration of glucose, better growth was always obtained in shaken or aerated cultures than with stationary 
conditions. However, shaking or aeration increased the specific activity of the enzyme only when glucose concentrations were low, e.g. at 0.5 and $0.25 \mathrm{mg} . / \mathrm{ml}$. At higher concentrations of glucose, oxygen no longer limited the enzyme synthesis. The interrelationship between glucose and oxygen would indicate that synthesis of the enzyme proceeds most efficiently only in fully respiring bacteria.

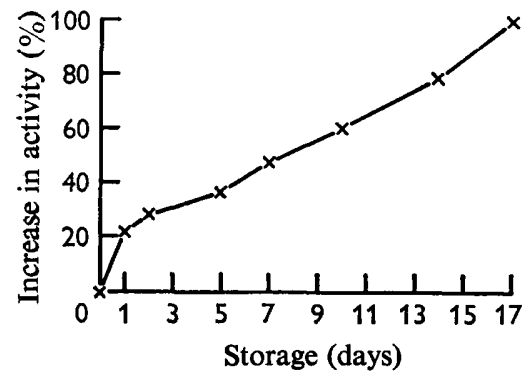

Fig. I

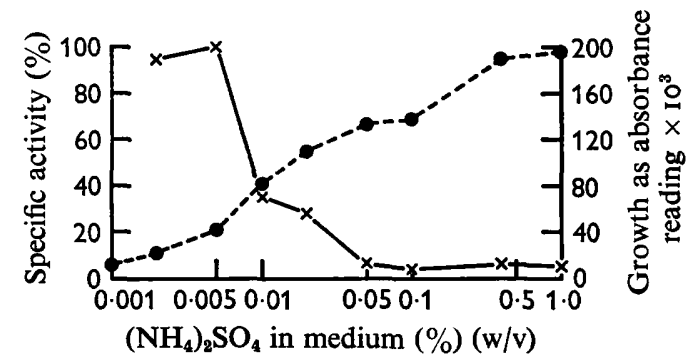

Fig. 2

Fig. I. Increase in glutamine synthetase activity in cell-free extracts of Escherichia coli strain w (ATCC 9637) during storage at $-20^{\circ} \mathrm{C}$.

Fig. 2. Dependence of growth and synthesis of glutamine synthetase in Escherichia coli strain w (ATCC 9637). on the concentration of ammonium sulphate in the basal medium. The specific activity of the enzyme is shown as a \% of the value obtained with $0.005 \%$ $\left(\mathrm{NH}_{4}\right)_{2} \mathrm{SO}_{4}$. Absorbance, - - - - enzyme activity, $\times-\times$.

Table I. Effect of glucose and oxygen on the synthesis of glutamine synthetase in Escherichia coli strain W (ATCC 9637)

The bacteria were grown in a defined medium with the concentration of glucose varied. During incubation, the medium was either left undisturbed (stationary), shaken, or aerated. The specific activity of the enzyme from the bacteria grown under stationary conditions with $2 \mathrm{mg}$. glucose $/ \mathrm{ml}$. averaged 16.8 units $/ \mathrm{mg}$. protein.

\begin{tabular}{|c|c|c|c|c|c|c|}
\hline & & & ndition & incubatior & & \\
\hline & Stati & ary & & & & \\
\hline $\begin{array}{c}\text { Glucose } \\
\text { (mg./ml.) }\end{array}$ & $\begin{array}{c}\text { Cell } \\
\text { growth* }\end{array}$ & $\begin{array}{c}\text { Relative } \\
\text { specific } \\
\text { activity } \\
(\%)\end{array}$ & $\begin{array}{c}\text { Cell } \\
\text { growth }\end{array}$ & $\begin{array}{c}\text { Relative } \\
\text { specific } \\
\text { activity } \\
(\%)\end{array}$ & $\begin{array}{c}\text { Cell } \\
\text { growth }\end{array}$ & $\begin{array}{c}\text { Relative } \\
\text { specific } \\
\text { activity } \\
(\%)\end{array}$ \\
\hline 0.25 & 0.027 & I4 & 0.042 & 57 & 0.055 & 52 \\
\hline 0.5 & 0.042 & 33 & 0.051 & 135 & 0.059 & 161 \\
\hline 2 & 0.046 & $(100)$ & 0.056 & 95 & $0.06 \mathrm{I}$ & 108 \\
\hline 4 & 0.042 & I IO & 0.064 & 103 & 0.068 & 129 \\
\hline
\end{tabular}

The repression of an enzyme synthesis by an end product of a reaction catalysed by that enzyme has been amply demonstrated in micro-organisms. Therefore it was not surprising to find repression of glutamine synthetase by glutamine in Escherichia coli, as shown in Table 2. The addition of glutamine also resulted in increased growth like that observed with ammonium sulphate (Fig. 2), and the concomitant decrease in specific activity approximated to that obtained with an equivalent amount of ammonium sulphate. The results in Table 2 show that glutamine also repressed, though to a 
lesser extent, the synthesis of glutamate dehydrogenase. This observation indicates that the reductive amination of $\alpha$-ketoglutarate to glutamate was in part utilized for glutamine synthesis. However, since Escherichia coli is known to have appreciable glutaminase activity, the possibility that glutamate, a hydrolytic product of glutamine, actually served as a repressor of glutamate dehydrogenase cannot be excluded.

Table 2. Repression of glutamate dehydrogenase and glutamine synthetase by glutamine in Escherichia coli strain W (ATCC 9537).

The bacteria were grown in basal medium with glutamine added. In these experiments, the assay of glutamine synthetase was done at $\mathrm{pH} 7 \cdot 2$.

\begin{tabular}{|c|c|c|}
\hline $\begin{array}{l}\text { L-Glutamine } \\
\text { (mM) }\end{array}$ & $\begin{array}{l}\text { Glutamate } \\
\text { dehydrogenase } \\
\text { ( } \mu \text { moles/mg. } \\
\text { protein/min.) }\end{array}$ & $\begin{array}{c}\text { Glutamine } \\
\text { synthetase } \\
\text { (m } \mu \text { moles } / \mathrm{mg} . \\
\text { protein/min.) }\end{array}$ \\
\hline 0 & 0.57 & 140 \\
\hline 3 & 0.42 & $39 \cdot 4$ \\
\hline 10 & 0.32 & 18.7 \\
\hline 30 & 0.26 & $7 \cdot 3$ \\
\hline 100 & 0.17 & 40 \\
\hline
\end{tabular}

Table 3. Effect of various amino acids on the synthesis of glutamine synthetase by Escherichia coli strain W (ATCC 9637)

In addition to $0.005 \%$ of ammonium sulphate, each amino acid was added to the basal medium to a final concentration of $10 \mathrm{~mm}$. The bacteria were harvested after $16 \mathrm{~h}$ of incubation at $37^{\circ}$. The bacteria grown in the medium without amino acid addition had a specific activity of glutamine synthetase of $12 \cdot 7$ units/mg. protein for glutamine synthetase.

$\begin{array}{lcc}\text { Amino acid } & \begin{array}{c}\text { Amount of } \\ \text { growth } \\ \text { (absorbance } \\ \text { reading) }\end{array} & \begin{array}{c}\text { Relative } \\ \text { specific } \\ \text { activity of } \\ \text { the enzyme } \\ (\%)\end{array} \\ \text { None } & 0.042 & (100) \\ \text { L-Arginine } & 0.133 & 22 \\ \text { L-Asparagine } & 0.178 & 16 \\ \text { L-Glutamic acid } & 0.147 & 18 \mathrm{I} \\ \text { L-Glutamine } & 0.209 & 9 \\ \text { D-Glutamine } & 0.172 & 63 \\ \text { Acetyl-L-glutamine } & 0.050 & 107 \\ \text { L-Isoleucine } & 0.065 & 120 \\ \text { L-Leucine } & 0.049 & 148 \\ \text { L-Methionine } & 0.094 & 14 \\ \text { L-Proline } & 0.041 & 96 \\ \text { L-Tryptophan } & 0.086 & 44 \\ \text { L-Valine } & 0.06 \mathrm{I} & 123\end{array}$

Table 3 shows the induction and repression of glutamine synthetase by other amino acids. We tested two analogues of glutamine, $N$-acetyl-L-glutamine and D-glutamine. Acetyl-L-glutamine slightly stimulated growth but exerted no effect on the enzyme synthesis. The acetyl group appears to have prevented the compound from either entering the cell as freely as glutamine or acting as a repressor of glutamine synthetase. D-Glutamine supported growth almost as well as did L-glutamine, but it repressed the enzyme synthesis to a much lesser extent than did L-glutamine. Glutamic acid was the 
only amino acid tested which nearly doubled the specific activity of the enzyme and tripled the bacterial population. Hence, the amount of the enzyme synthesized in the culture with glutamate was about six times that without the amino acid; this amount was further increased by increasing the concentration of glutamate above $10 \mathrm{~mm}$.

Other amino acids showed varied effects on the synthesis of glutamine synthetase. The three branched-chain amino acids, isoleucine, leucine and valine, increased significantly the specific activity of the enzyme in the bacteria, although there was no evidence that they were converted to glutamic acid. But arginine, asparagine, and methionine decreased the enzyme synthesis. Generally speaking, the amino acids which stimulated growth decreased the enzyme synthesis, and vice versa. In other words, the synthesis of the enzyme lagged far behind the synthesis of cellular proteins. Therefore, as growth proceeded, the specific activity of the enzyme diminished.

Since the bacteria could fully utilize D-glutamine for growth with only a slight decrease in the enzyme synthesis, we became interested in learning whether D-glutamine was active as a substrate of the enzyme. The $\gamma$-glutamyltransferase activity of the enzyme, which normally requires L-glutamine as a substrate, was therefore assayed. We found that this transferase activity in the extract of bacteria grown in the absence of any added amino acid amounted to $50.8 \mathrm{units} / \mathrm{mg}$. protein with L-glutamine as a substrate, but it approached only 9.2 units $/ \mathrm{mg}$. protein with D-glutamine. Hence, D-glutamine had $18 \%$ of the activity of L-glutamine. This low activity of the D-isomer for the enzyme may be related to the small repression of enzyme synthesis by this compound.

Table 4. Effectiveness of amino acids as the sole source of nitrogen for the synthesis of glutamine synthetase by Escherichia coli strain W (ATCC 9637)

Each amino acid replaced ammonium sulphate in the basal medium and supplied the same amount of nitrogen as that of $0.005 \%(0.38 \mathrm{~mm})$ of ammonium sulphate. The specific activity of glutamine synthetase in the bacteria grown in the medium with ammonium sulphate averaged $14^{\circ} \mathrm{O}$ units/mg. protein in these experiments.

\begin{tabular}{lccc}
\multicolumn{1}{c}{ Compound } & $\begin{array}{c}\text { Incubation } \\
\text { time (hr) }\end{array}$ & $\begin{array}{c}\text { Cell growth } \\
\text { (absorbance } \\
\text { reading) }\end{array}$ & $\begin{array}{c}\text { Relative } \\
\text { specific } \\
\text { activity of } \\
\text { the enzyme } \\
\text { (\%) }\end{array}$ \\
Ammonium sulphate & I6 & 0.041 & $(\mathrm{I00})$ \\
L-Arginine & 22 & 0.050 & 50 \\
L-Asparagine & 16 & 0.074 & 45 \\
L-Glutamic acid & 36 & 0.055 & 105 \\
L-Glutamine & 22 & 0.024 & 96 \\
L-Leucine & 96 & 0.033 & 137 \\
L-Methionine & 96 & 0.031 & 63 \\
L-Proline & 96 & 0.022 & 54
\end{tabular}

In the experiments just described, a relatively high concentration of an amino acid, Io mM, supplemented the optimal concentration of ammonion sulphate, $0.38 \mathrm{~mm}$, in the basal medium for the enzyme synthesis. In the following experiments, the ammonium sulphate was replaced by an amino acid solution containing 0.76 milliequivalent of nitrogen per litre. As can be seen in Table 4, only asparagine supported better growth than did the inorganic salt. Growth with each of the other amino acids showed an extended period of the lag phase, which, in certain instances, might have resulted from a low permeability of the cell membrane to the amino acids, such as glutamic 
acid. Although asparagine stimulated growth, it decreased synthesis of glutamine synthetase. On the other hand, glutamine appeared to be inferior to asparagine for growth, but it did not repress the enzyme synthesis. Conceivably, the optimal concentration of one amino acid for the enzyme synthesis may differ from that of another amino acid.

The compounds aza-L-serine and 6-diazo-3-oxo-L-norleucine (DON) have been shown to be specific antagonists of glutamine (Levenberg, Melnick \& Buchanan, 1957). They have also been shown to inhibit growth of Escherichia coli (Kaplan, Reilly \& Stock, 1959; Maxwell \& Nickel, 1957). These findings suggested that, if concentrations of the compounds were so low in the basal medium that no inhibition of growth

Table 5. Effect of azaserine and 6-diazo-5-oxo-L-norleucine on the growth and synthesis of glutamine synthetase in Escherichia coli strain W (ATCC 9637)

\begin{tabular}{|c|c|c|c|}
\hline \multicolumn{2}{|c|}{$\begin{array}{l}\text { Compound } \\
(\mathrm{m} \mu \mathrm{g} . / \mathrm{ml} .)\end{array}$} & $\begin{array}{l}\text { Amount of } \\
\text { growth } \\
\text { (absorbance } \\
\text { reading) }\end{array}$ & $\begin{array}{c}\text { Relative } \\
\text { specific } \\
\text { activity of } \\
\text { the enzyme } \\
(\%)\end{array}$ \\
\hline \multirow[t]{7}{*}{ Azaserine } & 0 & 0.046 & $(100)^{*}$ \\
\hline & 5 & 0.040 & 113 \\
\hline & 10 & 0.039 & 117 \\
\hline & 20 & 0.038 & 133 \\
\hline & 40 & 0.037 & I2I \\
\hline & 50 & 0.040 & 90 \\
\hline & 100 & 0.020 & 63 \\
\hline \multirow[t]{6}{*}{ DON } & 0 & 0.043 & $(100)^{*}$ \\
\hline & 0.5 & 0.048 & 107 \\
\hline & I & 0.052 & 126 \\
\hline & $2 \cdot 5$ & 0.060 & 102 \\
\hline & 5 & 0.054 & 44 \\
\hline & 10 & 0.030 & 26 \\
\hline
\end{tabular}

* This percentage corresponds to a specific activity of $16 \cdot 8$ units/mg. protein.

resulted, the antagonism to glutamine might then induce the bacteria to synthesize more glutamine, and hence more glutamine synthetase. Table 5 shows the results of these experiments. Azaserine did not appear to inhibit growth at concentrations as high as $50 \mathrm{~m} \mu \mathrm{g}$. DON/ml., being more toxic to the organism, began to inhibit growth at concentrations above $5 \mathrm{~m} \mu \mathrm{g}$. $/ \mathrm{ml}$.; below this concentration growth appeared to be somewhat stimulated by DON. Indeed, as expected, within the concentrations of these compounds which did not inhibit growth, the synthesis of glutamine synthetase was increased. Under the most favourable conditions, the increase amounted to $30 \%$ above the control value, a significant though slight increase. Addition of azaserine or DON to the reaction mixture to a final concentration of I $3 \mu \mathrm{g} . / \mathrm{ml}$. did not inhibit glutamine synthetase activity.

\section{DISCUSSION}

Repression of glutamine synthetase by L-glutamine has been observed in mammalian cells in culture (DeMars, I958; Paul \& Fottrell, 1963), in germinating wheat grains (Rijven, I96I), and in bacteria (Ravel, Humphreys \& Shive, 1965). In addition to 
L-glutamine, we have found that other amino acids also are capable of decreasing the synthesis of this enzyme. The ability of D-glutamine to repress the enzyme formation in Escherichia coli seems to result from its appreciable biological activity as a substrate of the enzyme in the $\gamma$-glutamyl transfer reaction. Levintow \& Meister (I953) reported that D-glutamine exhibited only about $I \%$ of the activity of L-glutamine for the enzyme from peas. Hence, D-glutamine, as a substrate in the transfer reaction, is more active for the bacterial enzyme than for the pea enzyme. In contrast, D-glutamate, as a substrate in the synthesis reaction, showed much less activity for the Escherichia coli enzyme (Woolfolk et al. I966) than for the pea enzyme (Levintow \& Meister, I953). Apparently, the bacterial enzyme shows low specificity for the L-isomer in the transfer reaction, but high specificity for the L-isomer in the synthesis reaction. The relative stereospecificity displayed by the two reactions of the same enzyme deserves further consideration.

Both ammonia and glutamate are substrates of glutamine synthetase. Hence, induction of the enzyme by glutamate can be readily understood. But contrary to expectation, ammonia represses the enzyme synthesis. Perhaps, in Escherichia coli, the synthesis of glutamine serves to a large extent as a storage for nitrogen. When the nitrogen supply is limited, the bacteria respond by converting as much inorganic nitrogen into glutamine as possible. Consequently, the bacteria synthesize more glutamine synthetase. However, when the nitrogen supply is plentiful, there is little need for storage, and the enzyme synthesis is kept at a minimum. Furthermore, we observed an inverse relationship between bacterial growth and the synthesis of glutamine synthetase when ammonia was the sole source of nitrogen and when amino acids other than glutamic acid supplemented ammonium sulphate as the major source of nitrogen. This inverse relationship suggests that the state of nitrogen metabolism of the growing bacteria can affect the synthesis of glutamine synthetase.

The demonstration that azaserine and DON increased the synthesis of glutamine synthetase leads us to speculate that both compounds exert their effect by virtue of their competitive inhibition with glutamine. These antibiotics are competitive inhibitors of glutamine in the synthesis of formylglycinamidine ribonucleotide (Levenberg et al. 1957). Thus, high concentrations of glutamine can abolish the inhibition. Possibly the bacteria respond to the presence of the inhibitors by synthesizing more glutamine, and hence more glutamine synthetase. In so doing, the bacteria appear to have succeeded in combating the inhibition, and thereby sustaining growth. Maxwell \& Nickel (I957) reported that glutamine, among other amino acids, could relieve the inhibition by azaserine and DON of the growth of Escherichia coli.

On the basis of indirect evidence obtained in the study of a partially purified preparation of glutamine synthetase from rat liver with ligands and cations, Wu (I964 $b$ ) deduced that the enzyme might contain a metal ion that inhibited its activity, and that the increase in activity following the addition of certain organic ligands might result from removal of the inhibitory ion originally bound to the enzyme. The recent demonstration by Woolfolk et al. (I966) that the crystalline bacterial glutamine synthetase contains $\mathrm{Mn}^{2+}$ seems to have substantiated this deduction. Since the results from this and previous $(\mathrm{Wu}, 1964 b)$ studies have shown that, under the conditions which are optimal for glutamine synthesis, $\mathbf{M n}^{2+}$ cannot replace $\mathbf{M g}^{2+}$, the rat liver enzyme and the Escherichia coli enzyme may be alike with respect to their metal-binding. 
This work was supported in part by research grants, AM-07319-04 and FR-05383-05, from the National Institutes of Health, U.S. Public Health Service.

This paper is no. VII in the series-Glutamine synthetase.

\section{REFERENCES}

Davis, B. D. \& Mingioli, E. S. (1950). Mutants of Escherichia coli requiring methionine or vitamin B $_{12}$. J. Bact. 6o, 17.

DeMars, R. (1958). The inhibition by glutamine of glutamyl transferase formation in cultures of human cells. Biochim. biophys. Acta 27, 435 .

Ghosh, S., Blumenthal, H. J., Davidson, E. \& Roseman, S. (1960). Glucosamine metabolism. V. Enzymatic synthesis of glucosamine-6-phosphate. J. biol. Chem. 235, 1265.

Kaplan, L., Reilly, H. C. \& Stock, C. C. (1959). Action of azaserine on Escherichia coli. J. Bact. 78, 5 II.

Kennan, A. L. \& Cohen, P. P. (1961). Ammonia detoxication in liver from humans. Proc. Soc. exp. Biol. Med. 106, 170.

Levenberg, B., Melnick, I. \& Buchanan, J. M. (1957). Biosynthesis of the purines. XV. The effect of aza-L-serine and 6-diazo-5-oxo-L-norleucine on inosinic acid biosynthesis de novo. J. biol. Chem. 225, 163 .

Levintow, L. \& Meister, A. (1953). Enzymatic synthesis of D-glutamine and related hydroxamic acids. J. Am. chem. Soc. 75, 3039.

Lowry, O. H., Rosebrough, N. J., FarR, A. L. \& Randall, R. J. (I95I). Protein measurement with the Folin phenol reagent. J. biol. Chem. 193, 265.

MAXwell, R. E. \& NiCKeL, V. S. (1957). 6-Diazo-5-oxo-L-norleucine, a new tumor-inhibitory substance. V. Microbiologic studies of mode of action. Antibiotics \& Chemother. 7, 8I.

MeCKE, D. \& Holzer, H. (1966). Repression und Inaktivierung von Glutaminsynthetase in Escherichia coli durch $\mathrm{NH}_{4}^{+}$. Biochim. biophys. Acta 122, 34I.

Mecke, D., WulfF, K. \& Holzer, H. (1966). Metabolit-induzierte Inaktivierung von Glutaminsynthetase aus Escherichia coli im zellfreien System. Biochim. biophys. Acta 128, 559.

MeCKE, D., WulfF, K., LeIss, K. \& Holzer, H. (I966). Characterization of a glutamine synthetase inactivating enzyme from Escherichia coli. Biochem. biophys. Res. Commun. 24, 452.

NeIDLE, A. \& WaELSCH, H. (1959). The origin of the imidazole ring of histidine in Escherichia coli. J. biol. Chem. 234, 586.

PAUL, J. \& FotTRELL, P. F. (1963). Mechanism of D-glutamyltransferase repression in mammalian cells. Biochim. biophys. Acta 67, 334 .

Pierard, A. \& Wiame, J. M. (I964). Regulation and mutation affecting a glutamine dependent formation of carbamyl phosphate in Escherichia coli. Biochem. biophys. Res. Commun. 15, 76.

Preiss, J. \& Handler, P. (1958). Biosynthesis of diphosphopyridine nucleotide. II. Enzymatic aspects. J. biol. Chem. 233, 493.

RAVEL, J. M., HumphreYs, J. S. \& Shive, W. (1965). Control of glutamine synthetase in Lactobacillus arabinosus. Arch. Biochem. Biophys. xn, 721.

RIJVEN, A. H. G. C. (196I). Regulation of glutamyl transferase level in germinating wheat embryos. Biochim. biophys. Acta 52, 213.

SCHNACKERZ, K. \& JAENICKE, L. (1966). Reinigung und Eigenschaften der Glutamin-Synthetase aus Schweinehirn. Hoppe-Seyler's Z. physiol. Chem. 347, 127.

SRINIVASAN, P. R. \& Weiss, B. (196I). The biosynthesis of $p$-aminobenzoic acid: studies on the origin of the amino group. Biochim. biophys. Acta 5I, 597.

Woolfolk, C. A., Shapiro, B. \& Stadtman, E. R. (1966). Regulation of glutamine synthetase. I. Purification and properties of glutamine synthetase from Escherichia coli. Arch.Biochem. Biophys. I16, 177.

WU, C. (1964a). Glutamine synthetase. IV. Its formation in rat liver following partial hepatectomy and during repletion. Arch. Biochem. Biophys. 106, 402.

Wu, C. (1964b). Glutamine synthetase. V. Dependence of its sulfhydryl requirement on organic ligands and metal ions. Biochim. biophys. Acta 89, 137. 